\title{
FACTORS IMPACTING WORK REMUNERATION IN THE CONTEXT OF SOCIAL SECURITY PROTECTION IN LATVIA
}

\author{
Baiba Mistre1, Mg.oec.; Anda Zvaigzne'2, Dr.oec. and Gunita Mazure ${ }^{3}$, Dr.oec. \\ ${ }^{1,3}$ Faculty of Economics and Social Development, Latvia University of Life Sciences and Technologies ${ }^{2}$ Research \\ Institute for Business and Social Process, Faculty of Economics and Business Management, \\ Rezekne Academy of Technologies
}

\begin{abstract}
In recent years, more and more scientists and society have been discussing the competitiveness of work remuneration and social security, which has a significant impact on the well-being of local people. Every country has a social security system that largely depends on the social and economic situation as well as on the social policy implemented in the country. The research hypothesis: it is possible to identify and group factors impacting work remuneration in social protection. The research aim is to study the factors impacting work remuneration in the context of social protection in Latvia. The research results confirm that the factors influencing the level of wages may be divided into macroeconomic, microeconomic and personal individual factors. Low work remuneration indicates on lower welfare and social protection of the population. The research includes a population survey carried out in Latgale region, since the average monthly gross salary is lower in this region compared with the other statistical regions of Latvia. The population survey data show that the most important personal individual factors influencing work remuneration are the position held and the level of education. The workplace in an international or local company as well as the length of service are other important factors. The lowest average rating of the population is given to other factors possibly impacting the level of work remuneration such as age, gender, health and marital status.
\end{abstract}

Key words: work remuneration, social protection, impacting factors.

JEL code: J310, J380, F5, R0

\section{Introduction}

The capacity and sustainable development of the social security system, which protects individuals in case of social risk and provides the disabled persons with the means of existence, play an important role in ensuring public welfare.

Risks or needs that may cause the necessity for social protection are as follows: sickness / health care; disability; age; loss of a provider; family / children; unemployment; housing; and social exclusion not classified elsewhere. The basis of social security for the protection of population in case of social risks and its main task is to reduce the incurred losses and their impact on the ability of people to provide themselves with sufficient quality of life in a particular life situation (Sociala aizsardziba, 2015).

Every country has a social security system that largely depends on the social and economic situation as well as on the social policy implemented in the country. In Latvia, the social security system includes the state social insurance, state social benefits, social assistance and social services.

Under the Law "On State Social Insurance" (1997), the purpose of the social insurance system is to insure the risk of loss of earnings of a person or its dependents due to illness, disability, maternity, unemployment, age, accident at work or occupational disease of a socially insured person as well as additional expenses for the care of the child and the death of the socially insured person or its dependents.

The social protection of a person is significantly influenced by the amount of the mandatory state social insurance contributions paid from the income (work remuneration).

Several researchers like A.Grinfelde (2010), I.Latviete (2012), E.Volskis (2008) and organisations such as Free Trade Union Confederation of Latvia $(2011,2014)$ have addressed social security and

\footnotetext{
$1+$ +Tel.: +37163024214 E-mail address: baiba.mistre@llu.Iv

2 E-mail address: anda.zvaigzne@rta.Iv

3 E-mail address: gunita.mazure@llu.Iv
} 
social protection issues in Latvia. In addition, social security issues are addressed in several studies by the Ministry of Welfare (Ministry of Welfare, 2019). I.Mietule (2012) and R.Liepina (2012) have summarised the factors influencing wages and analysed the trends of wage changes by sectors and regions in Latvia.

The research hypothesis: it is possible to identify and group factors impacting work remuneration in social protection.

The research aim is to study the factors impacting work remuneration in the context of social protection in Latvia.

The following tasks are subjected to the set aim:

1) to analyse the importance of work remuneration and factors related with it;

2) to assess the factors impacting work remuneration for the provision of social protection.

Research methods: monographic and descriptive methods, analysis and synthesis, graphic method, statistical method (time-series analysis, data grouping, analysis of intersection tables etc.) and sociological research methods - surveys of experts and population. The Affinity diagram is applied to systematise the expert opinions.

The present research is based on various scientific publications, publicly available documents, information available in databases and other sources.

\section{Research results and discussion}

\section{Work remuneration and factors impacting it}

Pursuant to the "Labour Law" (2001), work remuneration is a regular pay for work payable to an employee, and which includes wages and salaries and supplements specified by regulatory enactments, the collective agreement or an employment contracts as well as bonuses and any other types of payments related with work (Darba likums, 2001).

Work remuneration helps employees get the resources they need to meet their needs (Darba algas un ..., 2006).

The amount of a person's social guarantees (pensions, social insurance benefits) is significantly influenced by the gross wage to personal insurance contributions and insurance period (length of service).

The notions "wage subject to insurance contributions" and "insurance period" are more related with the calculation of state pensions and social insurance benefits.

According to the Law "On Maternity and Sickness Insurance" (1995), the wage subject to insurance contributions is the income from which the state social insurance contributions have been made.

Pursuant to the law "On State Social Insurance" (1997), the employer has to calculate the mandatory state social insurance contributions for each employee from the object of contributions and pay it into a special budget account.

The object of mandatory contributions of an employer and employee is all calculated income for work from which the personal income tax shall be withheld, without deduction of the non-taxable minimum, tax reliefs and eligible expenses for which the taxpayer is entitled to reduce the taxable income.

The object of mandatory contributions of a self-employed person is freely selected income from the production of goods, performance of work, provision of services, creative and professional activity and other income from the economic activity. 
The European Social Charter states that all employees and workers have the right to a fair work remuneration that is sufficient to ensure decent living conditions for themselves and their families as well as the right to social protection (Par Eiropas Socialo..., 2001).

The interaction between the labour demand and supply determines the level of work remuneration (Erenberga R.G., Smita S.R., 2012). Labour demand depends on the demand for products and services as well as labour productivity. Labour productivity, in turn, depends on technologies, natural resources, quality of labour force, administration and organisation. Therefore, the demand for labour is simultaneously determined both by the individuals as characteristics of certain human resources and the technical resources and the work organisation of a particular company carried out by the company manager as well as the macroeconomic environment in the country (Darba algas un ..., 2006).

Professor V.Gaga (2013) emphasises that the level of labour productivity is affected by the level of the extensive use of work and the technical and technological condition of production.

The extensive characterisation of work reflects the degree of use of working time and its duration in a shift, while the other characteristics remain unchanged. The more working hours are used, the less is idle time and time consumption not related with the production; and the longer is the shift, the higher is work productivity. There are two visible boundaries to the extensive characterisation of work: the duration of a working day and the duration of a working week set by the legislator (Gaga V., 2013).

G.Libermanis (2006) admits that the demand for labour is influenced by the demand for performances of outstanding musicians, artists, actors, directors, writers, sportsmen and a variety of different "stars".

Labour supply is determined by the number of population in certain age groups, the institutional environment (regulatory framework) and alternative sources of income, for example, the possibilities to work abroad, the level of pensions and benefits etc. Labour supply is also determined by the labour supply of immigrants and the readiness to work for a significantly lower salary (Libermanis, 2006).

The level of wages is determined by investments in human capital (education and health care). This is expressed both at the individual level (a person who has invested in education receives a higher salary) and at the company level (depending on the company's investment in training of employees).

Investing in human capital makes people more productive and emotionally richer. It is essential to maintain the base value of human capital and to increase its productivity in Latvia due to the decrease in the number of population and aging of the society (Latvijas ilgtspejigas attistibas ..., 2010).

Researchers Siebert et al. indicate that a vocational training or a university degree is the requirement of an employer for skilled workers to avoid precarious working conditions. It is also related with the duration of employment, which, in turn, is linked to the quality of life as it affects the social life and involves a number of risk factors such as insecurity of employee income (Siebert A.A. et al., 2018).

Salaries and wages are influenced by various political, institutional (provisions of legal and regulatory enactments, activities of trade unions etc.), social and psychological factors. The wage gap from the market level is determined by the size of the company, the competitive labour force situation and the personnel management strategy (Darba samaksas un ..., 2014).

The following competitiveness aspects either directly or indirectly impact the work remuneration: 
- GDP volume and its dynamics, and the welfare of population;

- GDP in terms of revenue, showing the distribution of revenue between the owners of labour and capital;

- labour taxes;

- minimum wage;

- costs of living characterised by the comparison of prices for goods and services;

- labour productivity and the structure of national economy (Darba samaksas un ..., 2014).

The study "Competitiveness of Wages and Social Guarantees in the Baltic States" (2014) concludes that the amount of GDP affects the level of wages (both the absolute GDP characterising the economic capacity and the relative GDP per capita characterising the general welfare of population), i.e. the wages are higher in the countries where GDP per capita is higher.

The minimum monthly wage is essential to ensure at least the minimum level of social protection for a person. A study by the Ministry of Welfare indicates that employers assess differently the impact of the increase of the minimum wage on the work remuneration in general. In companies with higher productivity, the increase of the minimum monthly wage does not have any impact on wages as they exceed the minimum wage. However, in companies with lower productivity and turnover, the size of work remuneration for the part of employees coincide with the minimum wage set in the country; thus, the employer has to increase wages irrespective of its possibilities (Darba algas un ..., 2006).

The level of work remuneration impacts the social protection of employees. Studies show that the main reason in Latvia for employees to leave and change work is higher remuneration (Velama videja menesalga, 2016). In turn, the reason for the employer to increase the salary is labour productivity. Nevertheless, different studies confirm that labour productivity has increased in recent years in Latvia. Higher labour productivity allows generating more value added per unit within a certain time unit and to raise work remuneration for employees (Saulaja I. et al., 2016).

Further the authors of the present research will determine the most important factors impacting work remuneration to ensure the social protection by means of the expert focus group discussion method.

\section{Assessment of the factors impacting work remuneration for the provision of social protection}

In November 2018, a discussion of the focus group experts was carried out within the framework of the research to identify the experts' opinion on the factors impacting the level of work remuneration for the provision of social protection of the population. Five experts participated in the focus group discussion. The criteria for selecting the experts were as follows: higher education; at least 5 years of experience in accounting or finance, calculation and planning of salaries and wages; experience in social protection; knowledge on the legal and regulatory enactments of the Republic of Latvia and the European Union in relation with the research topic. Selected experts represented different organisations: municipalities, businesses, consultancy and education institutions.

Based on the results of the focus group survey, the authors grouped the factors impacting the level of work remuneration using the Affinity diagram method, which was developed by Jiro Kawakita in the 1960s. The Affinity diagram is a method that helps systematise information, group data or topics. The diagram is suitable for the particular research to group the data from studies and ideas resulting from the focus group discussion and brainstorm (Using Affinity Diagrams..., s.a.). 
Experts identified the most important factors impacting work remuneration and divided them into macroeconomic, microeconomic and personal individual factors.

Macroeconomic factors were subdivided into the following groups: social, technological, economic, political and legal factors (Table 1 ).

Table 1

\section{Affinity diagram - factors impacting the level of work remuneration based on} the expert focus group discussion results

\begin{tabular}{|c|c|c|c|c|c|}
\hline \multicolumn{4}{|c|}{ Macroeconomic factors } & \multirow{2}{*}{$\begin{array}{l}\text { Micro- } \\
\text { economic } \\
\text { factors }\end{array}$} & \multirow{2}{*}{$\begin{array}{c}\text { Personal } \\
\text { individual } \\
\text { factors }\end{array}$} \\
\hline Social & Technological & Economic & $\begin{array}{c}\text { Political and } \\
\text { legal }\end{array}$ & & \\
\hline $\begin{array}{l}\text { Number of } \\
\text { population in } \\
\text { certain age } \\
\text { groups }\end{array}$ & $\begin{array}{l}\text { Technology } \\
\text { development } \\
\text { trends }\end{array}$ & $\begin{array}{l}\text { Price of labour } \\
\text { force }\end{array}$ & $\begin{array}{l}\text { Regulation of } \\
\text { work remune- } \\
\text { ration } \\
\text { (minimum } \\
\text { wage) }\end{array}$ & $\begin{array}{c}\text { Financial } \\
\text { situation of the } \\
\text { company }\end{array}$ & $\begin{array}{l}\text { Length of service, } \\
\text { education level of } \\
\text { employees } \\
\text { (knowledge, } \\
\text { skills, } \\
\text { competences) }\end{array}$ \\
\hline $\begin{array}{l}\text { Trends of } \\
\text { immigration } \\
\text { and emigration }\end{array}$ & $\begin{array}{l}\text { Technical and } \\
\text { technological } \\
\text { state of } \\
\text { production }\end{array}$ & $\begin{array}{c}\text { GDP amount and } \\
\text { dynamics }\end{array}$ & \multirow{2}{*}{$\begin{array}{l}\text { Tax legislation } \\
\text { (labour taxes) }\end{array}$} & $\begin{array}{l}\text { Remuneration } \\
\text { system in the } \\
\text { company }\end{array}$ & $\begin{array}{l}\text { Position held, } \\
\text { career growth } \\
\text { opportunities }\end{array}$ \\
\hline $\begin{array}{l}\text { Employees' } \\
\text { level of } \\
\text { knowledge and } \\
\text { skills }\end{array}$ & $\begin{array}{c}\text { Development of } \\
\text { e-commerce }\end{array}$ & Costs of living & & $\begin{array}{l}\text { Company } \\
\text { activity sector }\end{array}$ & $\begin{array}{c}\text { Type of company } \\
\text { (local, } \\
\text { international) }\end{array}$ \\
\hline \multirow{2}{*}{$\begin{array}{l}\text { Attitude } \\
\text { towards work } \\
\text { (dependency on } \\
\text { social benefits), } \\
\text { health, leisure }\end{array}$} & \multirow{2}{*}{$\begin{array}{l}\text { Availability of } \\
\text { prices of software }\end{array}$} & $\begin{array}{l}\text { Unemployment } \\
\text { rate }\end{array}$ & \multirow{2}{*}{$\begin{array}{c}\text { National social } \\
\text { policy and the } \\
\text { EU } \\
\text { programmes }\end{array}$} & \multirow{2}{*}{$\begin{array}{l}\text { Geographical } \\
\text { location of the } \\
\text { company, } \\
\text { market, sales } \\
\text { (export) } \\
\end{array}$} & \multirow{4}{*}{$\begin{array}{c}\text { Other: age, } \\
\text { gender, health } \\
\text { situation, marital } \\
\text { status etc. }\end{array}$} \\
\hline & & Employment rate & & & \\
\hline \multirow[b]{2}{*}{$\begin{array}{l}\text { Other: } \\
\text { development of } \\
\text { social } \\
\text { innovation and } \\
\text { entrepreneursh } \\
\text { ip etc. }\end{array}$} & \multirow{2}{*}{$\begin{array}{c}\text { Other: } \\
\text { possibilities to use } \\
\text { artificial } \\
\text { intelligence in } \\
\text { various sectors } \\
\text { etc. }\end{array}$} & $\begin{array}{c}\text { Comparative } \\
\text { advantages of the } \\
\text { regions }\end{array}$ & \multirow{2}{*}{$\begin{array}{c}\text { Other: } \\
\text { opportunities } \\
\text { of the } \\
\text { population to } \\
\text { work abroad } \\
\text { etc. }\end{array}$} & \multirow{2}{*}{$\begin{array}{c}\text { Other: } \\
\text { social } \\
\text { contributions } \\
\text { and other } \\
\text { economic } \\
\text { benefits to } \\
\text { employees, } \\
\text { investment in } \\
\text { human capital } \\
\text { etc. }\end{array}$} & \\
\hline & & $\begin{array}{l}\text { Other: inflation } \\
\text { rate etc. }\end{array}$ & & & \\
\hline
\end{tabular}

\section{Source: authors' research}

The expert focus group discussion was followed by a more in-depth population survey using the individual factors influencing the level of work remuneration determined by experts: length of service, level of education, career opportunities, type of company (local, international) and others: age, gender, health situation, marital status etc.

The research incorporated also a population survey, which was done in Latgale region, as the average monthly gross wage is the lowest there in comparison with the other regions of Latvia (Table 2). In 2017, wages in Latgale region were by 38.7 \% lower than in Riga region and by $26.5 \%$ lower than in Pieriga region. Low work remuneration indicates on lower welfare and social protection of the population. The calculated chain growth rates characterise the intensity of changes in the gross wage level in the regions of Latvia. In 2017, the most rapid increase in the average gross wage was observed in all regions of Latvia, which was influenced both by the increase of the minimum monthly wage and the improvement of the economic situation in the country. 
The average monthly gross work remuneration in the regions of Latvia between 2013 and 2017

\begin{tabular}{|l|c|c|c|c|c|c|c|c|c|}
\hline \multirow{2}{*}{ Region } & \multicolumn{4}{|c|}{ Average monthly gross work remuneration, EUR } & \multicolumn{4}{c|}{ Chain growth rate, \% } \\
\cline { 2 - 11 } & $\mathbf{2 0 1 3}$ & $\mathbf{2 0 1 4}$ & $\mathbf{2 0 1 5}$ & $\mathbf{2 0 1 6}$ & $\mathbf{2 0 1 7}$ & $\mathbf{2 0 1 4}$ & $\mathbf{2 0 1 5}$ & $\mathbf{2 0 1 6}$ & $\mathbf{2 0 1 7}$ \\
\hline Riga & 815 & 869 & 925 & 971 & 1044 & 6.63 & 6.44 & 4.97 & 7.52 \\
\hline Pieriga & 677 & 721 & 770 & 806 & 871 & 6.50 & 6.80 & 4.68 & 8.06 \\
\hline Vidzeme & 560 & 598 & 643 & 675 & 739 & 6.79 & 7.53 & 4.98 & 9.48 \\
\hline Kurzeme & 608 & 651 & 693 & 716 & 775 & 7.07 & 6.45 & 3.32 & 8.24 \\
\hline Zemgale & 597 & 645 & 683 & 725 & 786 & 8.04 & 5.89 & 6.15 & 8.41 \\
\hline Latgale & 490 & 522 & 564 & 592 & 640 & 6.53 & 8.05 & 4.96 & 8.11 \\
\hline Latvia & 716 & 765 & 818 & 859 & 926 & 6.84 & 6.93 & 5.01 & 7.80 \\
\hline
\end{tabular}

Source: authors' construction based on the data of the Central Statistical Bureau (CSB), 2018

In total, 661 inhabitants of Latgale region participated in the evaluation of personal individual factors impacting the level of work remuneration. The questionnaire with the criteria to be evaluated was distributed electronically and in a printed form, and the residents were interviewed by telephone. The research period was from October 2018 to January 2019. The statistical data package SPSS (Statistical Package for the Social Science) and Microsoft Excel analysis tools were used to process the research results.

The questionnaire was developed so that the population assessed the personal individual factors impacting the level of work remuneration using the Likert scale in a 5-point system from 1 (lowest rating, i.e. with the lowest impact) to 5 (highest rating, i.e. with the highest impact on the level of work remuneration).

The survey data show that the highest rating (with 5 points) among the personal individual factors impacting the level of work remuneration have received the following factors: the position held and the level of education; these are the factors that mostly impact the level of work remuneration (Table 3).

Table 3

Breakdown of the respondents' answers in a 5-point system assessing the personal individual factors impacting the level of work remuneration, \%

\begin{tabular}{|c|c|c|c|c|c|}
\hline \multirow{2}{*}{ Personal individual factors } & \multicolumn{5}{|c|}{$\begin{array}{c}\text { Breakdown of the respondents' }(n=661) \\
\text { assessment, \% }\end{array}$} \\
\hline & 1 & 2 & 3 & 4 & 5 \\
\hline $\begin{array}{l}\text { Education level of employees (knowledge, skills, } \\
\text { competences) }\end{array}$ & 3 & 5 & 17 & 38 & 37 \\
\hline Career growth opportunities & 4 & 10 & 23 & 33 & 30 \\
\hline Position held & 3 & 5 & 15 & 34 & 43 \\
\hline Length of service & 4 & 9 & 21 & 40 & 26 \\
\hline Workplace - local company & 5 & 10 & 23 & 41 & 21 \\
\hline Workplace - international company & 4 & 9 & 21 & 41 & 25 \\
\hline $\begin{array}{l}\text { Other: age, gender, health situation, marital status } \\
\text { etc. }\end{array}$ & 10 & 15 & 28 & 31 & 16 \\
\hline
\end{tabular}

Source: authors' research

The highest percentage of respondents have assessed the following factors: job at international and local company as well as the length of service. These factors received 4 points. This means that the position held in the company and the level of education obtained significantly impact the level of social protection, and hence, the quality of life. 
Analysing the survey results by means of the statistical methods, the average indicators are one of the most important figures. The average arithmetic figure is the sum of all variants of the sample set divided by the number of variants. Table 4 shows the average and mean indicators for the assessment of personal individual factors impacting the level of work remuneration.

The average and mean indicators for the assessment of personal individual factors impacting the level of work remuneration $(n=661)$

\begin{tabular}{|l|c|c|}
\hline \multicolumn{1}{|c|}{ Criterion } & Mean & Average \\
\hline $\begin{array}{l}\text { Education level of employees (knowledge, skills, } \\
\text { competences) }\end{array}$ & 4 & 4.01 \\
\hline Career growth opportunities & 4 & 3.74 \\
\hline Position held & 5 & 4.10 \\
\hline Length of service & 4 & 3.72 \\
\hline Workplace - local company & 4 & 3.63 \\
\hline Workplace - international company & 4 & 3.75 \\
\hline Other: age, gender, health situation, marital status etc. & 4 & 3.29 \\
\hline
\end{tabular}
Source: authors' research

In general, it should be concluded that the respondents' assessment of the position held as the individual factor influencing the salary level is high. The lowest average rating is given to other factors such as age, gender, health situation, marital status etc.

\section{Conclusions}

1) Work remuneration helps employees obtain the necessary resources to meet their needs. The level of work remuneration impacts the social protection and well-being of employees, while the level of work remuneration is determined by the interaction between labour demand and supply.

2) The factors impacting work remuneration based on the expert focus group discussions and using the Affinity diagram method were divided into three groups: macroeconomic, microeconomic and personal individual factors. Macroeconomic factors were subdivided into the following groups: social, technological, economic, political and legal factors. The research hypothesis was confirmed.

3) Within the research, a population survey was done in Latgale region, as the average monthly gross wage during the entire period analysed is the lowest there in comparison with the other regions of Latvia.

4) The population survey data analysis shows that the position held and the education level are the most significant personal individual factors impacting the level of work remuneration, and hence, the social protection. Other significant factors include a workplace in an international and local companies as well as the length of service. The least significant factors resulting from the population survey are age, gender, health situation and marital status.

\section{Bibliography}

1. Darba algas un to ietekmejosie faktori. Eiropas Savienibas strukturfondu nacionalas programmas "Darba tirgus petijumi" projekts "Labklajibas ministrijas petijumi" (Wages and Factors Impacting Work Remuneration. Project of the EU "Studies of Labour Market") Nr. VPDI/ESF/NVA/04/NP/3.1.5.1./0001/0003. Riga, 2006, 206 Ipp.

2. Darba samaksas un socialo garantiju konkuretspeja Baltijas regiona (Competitiveness of Wages and Social Guarantees in the Baltic Region) (2014). Retrieved: http://www.sif.gov.Iv/nodevumi/nodevumi/3418/darba_samaksas_un_socialo_garantiju_konkuretspeja_balt ijas_regiona.pdf Access: 15.01.2019. 
3. Ehremberg R.G., Smith S.R. (2012). Modern Labor Economics, London, Retrieved: file://C:/Users/data/Desktop/Modern_labor_economics_theory_and_public_policy_0.pdf Access: 24.01.2019.

4. Free Trade Union Confederation of Latvia (2011). Social Security Policy in Latvia in Times of Crisis. Methodological material. Riga, p. 55.

5. Gaga V. (2013). Darba ekonomikas un sociologijas daudzlimenu sistemas. Monografija (Multi-level Systems of Labour Economy and Sociology. Monograph). Retrieved: http://vladimirgaga.com/images/abook/Darba_ekonomika_III.pdf. Access: 15.11.2018.

6. Grinfelde A. (2010). Life Quality of Pensioners in Latvian Regions. Summary of doctoral thesis. Jelgava, p.113.

7. Latviete I. (2012). European Social Fund Financing in the Welfare Sector in the Regions of Latvia. Summary of doctoral thesis. Jelgava, p.128.

8. Latvijas ilgtspejigas attistibas strategija 2030.gadam (2010) (Latvia's Sustainable Development Strategy for 2030). Retrieved: http://polsis.mk.gov.lv/documents/3323. Access: 24.01.2019.

9. Libermanis G. (2006). Mikroekonomika (Microeconomics). Riga: Kamene, 371. Ipp.

10. Mietule I., Liepina, R. (2012). Wage Trends in Latvia during the Downturn in Economy. Retrieved: http://www.rta.Iv/uploads/source/content_EN/Science \%20publications/Journal \%20of \%20Social \%20scien ces/Nr_1(4).pdf. Access: 24.01.2019.

11. Ministry of Welfare of the Republic of Latvia (2019). Nozares politika. Darba tirgus. Publikacijas, petijumi un statistika (Sectoral Policy. Labour Market. Publications, Studies and Statistics). Retrieved: http://www.Im.gov.Iv/Iv/nozares-politika/darba-tirgus/darba-tirgus-statistika-un-petijumi/labklajibasministrijas-petijumi-13-nacionalas-programmas-petijumi. Access: 24.01.2019.

12. On Maternity and Sickness Insurance (1995). The Law of the Republic of Latvia. Retrieved: https://likumi.Iv/ta/en/en/id/38051. Access: 24.01.2019.

13. On State Social Insurance (1997). The Law of the Republic of Latvia. Retrieved: https://likumi.Iv/ta/en/en/id/45466. Access: 24.01.2019.

14. Par Eiropas Socialo hartu (On European Social Charter) (2001) Retrieved: https://likumi.Iv/ta/id/56569-pareiropas-socialo-hartu. Access: 24.01.2019.

15. Saulaja, I., Zvaigzne, A., Mietule, I. (2016). Labour Costs and Productivity in Latvia. Economics Science for Rural Development: Integrated and Sustainable Regional Development, Production and Co-operation in Agriculture. No 42. Jelgava: LLU, pp. 150-156.

16. Siebert A.A., O'Keeffe S., Thrän D. (2018). Social Life Cycle Assessment Indices and Indicators to Monitor the Social Implications of Wood-based Products. Retrieved: https://www.sciencedirect.com/science/article/pii/S0959652617303724?via \%3Dihub. Access: 24.05.2018.

17. Sociala aizsardziba (Social Protection) (2015). Retrieved: http://www.csb.gov.Iv/statistikastemas/termini/sociala-aizsardziba-36143.html. Access: 24.02.2018.

18. Stradajoso menesa videja darba samaksa statistiskajos regionos (Average Monthly Wage of Employed by the Statistical Regions). Statistics Database. Retrieved: https://www.csb.gov.Iv/lv/statistika/statistikastemas/socialie-procesi/darba-samaksa/tabulas/dsg050/stradajoso-menesa-videja-darba-samaksa. Access: 14.01.2019.

19.Using Affinity Diagrams to Make Sense from Brainstorming. Retrieved: http://www.leanyourcompany.com/methods/Using-Affinity-Diagrams.asp. Access: 24.01.2019.

20. Velama videja menesalga "uz rokas" butiski parsniedz videjo algu valsti (Desirable Net Average Monthly Salary Significantly Exceeds the Average Salary in the Country) (2016). Retrieved: http://www.kantartns.Iv/velama-videja-menesalga-uz-rokas-butiski-parsniedz-videjo-algu-valsti/. Access 24.01.2019.

21. Volskis E. (2008). Pension System's Development Problems in Latvia. Summary of PhD paper. Riga, p. 31. 